ADAM BARTCZAK

Wydział Prawa i Administracji

Uniwersytetu Łódzkiego

ORCID: 0000-0001-6074-2872

\title{
PROCES DOKUMENTALNY A PROCES SKRÓCONY PRZED BISKUPEM - PROCESY SPECJALNE W SPRAWACH DE NULLITATAE
}

Treść: Wstęp. - 1. Proces o orzeczenie nieważności małżeństwa. - 2. Cel procesu dokumentalnego i skróconego przed biskupem. - 3. Forma procesu dokumentalnego i skróconego przed biskupem. - 3.1. Skarga powodowa. - 3.2. Czynności wstępne. 3.3. Zawiązanie sporu i wybór trybu procesu. - 3.4. Faza dowodowa. - 3.5. Faza dyskusji. - 4. Sędzia w procesie. - 5. Decyzja sędziego. - Zakończenie.

\section{Wstęp}

Nowelizacja Kodeksu Prawa Kanonicznego z 1983 r. dokonana Motu proprio papieża Franciszka Mitis iudex Dominus Iesus z 15 sierpnia 2015 r. wprowadziła nowe spojrzenie na proces małżeński. Nowe przepisy odnosiły się w większości do procesu zwyczajnego. Jedną z nowości było wprowadzenie procesu skróconego przed biskupem. W mocy pozostały przepisy dotyczące procesu dokumentalnego, choć i tam znalazły się pewne zmiany. Omawiana nowelizacja dała równoczesną możliwość funkcjonowania dwóch procesów skróconych. Pojawia się zatem pytanie czy mamy do czynienia z uzupełnieniem pewnych luk czy może swoistym nadmiarem prawa? Relacja obydwu procesów względem siebie i procesu zwyczajnego przyświeca zatem poniższym rozważaniom. 


\section{Proces o orzeczenie nieważności małżeństwa}

Trybunały kościelne stanowią miejsce, w którym Kościół mocą własnego i wyłącznego prawa rozpoznaje sprawy dotyczące rzeczy duchowych i związanych z duchowymi a także przekroczenie ustaw kościelnych oraz wszystkie inne, w których wchodzi w grę grzech, w tym co dotyczy ustalenia winy i wymierzenia kar kościelnych ${ }^{1}$. W praktyce przeważająca większość spraw dotyczy orzeczenia nieważności małżeństwa. Można by rzec, że trybunały kościelne stały się swoistymi sądami małżeńskimi, właśnie ze względu na liczbę spraw tej materii. Mamy więc do czynienia z procesami wnoszonymi przez małżonka, rzadziej małżonków, w których zaskarżają oni swoje małżeństwo. Oznacza to w praktyce chęć z ich strony, przynajmniej sprawdzenia czy ich małżeństwo zostało zawarte nieważnie, jeśli nawet nie wprost, notabene błędnie, oczekiwanie rozwiązania małżeństwa na wzór rozwodu cywilnego ${ }^{2}$. Tymczasem proces o stwierdzenie nieważności małżeństwa jest jednym z procesów małżeńskich rozpatrywanych przed sądami kościelnymi. Obok niego wyróżnić możemy bowiem procesy o separację małżonków, które mogą przybierać formę sądową lub administracyjną oraz procesy o dyspensę od małżeństwa zawartego i niedopełnionego lub procesy dotyczące domniemanej śmierci współmałżonka, o charakterze czysto administracyjnym. Bez wątpienia proces o orzeczenie nieważności małżeństwa ma charakter stricte sądowy. Te procesy rozpatruje się według specjalnego postępowania ${ }^{3}$, przed trybunałem kompetentnym do podjęcia decyzji. Punktem centralnym tego procesu jest wydanie decyzji (wyroku) czy dane małżeństwo zostało zawarte nieważnie i pozostaje nieważne $z$ konkretnego tytułu (tytułów) prawnego. W ten

\footnotetext{
${ }^{1}$ Por. kan. 1401 KPK.

${ }^{2}$ Por. kan. $1671 \$ 2$ KPK/MIDI. „Sprawy dotyczące czysto cywilnych skutków małżeństwa należą do władzy świeckiej, chyba że prawo partykularne stanowi, że jeżeli sprawy te są traktowane wpadkowo i dodatkowo, mogą być rozpoznawane i rozstrzygane przez sędziego kościelnego". Por także A. BARTCzAK, Ignorantia iuris nocet. Kilka uwag z pracy kancelarii trybunału kościelnego, Łódzkie Studia Teologiczne 26 (2017) 4, s. 66.
}

${ }^{3}$ Por. kan. 1671-1691 KPK/MIDI. 
sposób sąd udziela odpowiedzi na wysuniętą wątpliwość przedłożoną w skardze powodowej ${ }^{4}$.

W procesie de nullitatae małżeństwo zaskarżyć mogą małżonkowie oraz promotor sprawiedliwości, kiedy nieważność została już rozgłoszona, jeżeli małżeństwo nie może zostać uważnione albo nie jest to wskazane ${ }^{5}$. W praktyce najczęściej skarżą swoje małżeństwo sami małżonkowie, a w zasadzie jeden z nich, który staje się $\mathrm{w}$ procesie stroną powodową. Drugi małżonek występuje odtąd jako strona pozwana. Warto podkreślić, iż mimo terminologii przyjętej $\mathrm{z}$ procesu spornego, strony w procesie zasadniczo mają takie sama prawa. Obowiązki zasadniczo różnią się w tym sensie, iż zgodnie z rzymską zasadą actor incumbit probatio, to na stronie powodowej spoczywa obowiązek dowodzenia. Strona pozwana zasadniczo więc korzysta z praw, nie wykluczając oczywiście i jej obowiązków ${ }^{6}$. Strony procesowe mogą skorzystać z prawa ustanowienia adwokata i pełnomocnika .

Po złożeniu skargi procesowej zgodnie z kan. 1504 KPK oraz art. 116 Instrukcji procesowej Dignitas connubii przed właściwy trybunał" trybunał winien podjąć przewidziane prawem kroki, aby zawiązać spór ${ }^{9}$. Zgodnie z kan. 1513 KPK, zawiązanie sporu ma miejsce wtedy, gdy dekretem sędziego, w oparciu o żądania i odpowiedzi stron, zostaje określony zakres sporu. Tym samym ustala się tytuły prawne co do których sąd będzie musiał dać odpowiedź w wydanym wyroku. $\mathrm{W}$ tym samym momencie wikariusz sądowy podejmuje decyzję co do tego czy sprawa ma być rozpatrywana w procesie zwykłym czy procesie skróconym przed biskupem. Jeśli wybrana została pierwsza możliwość, konstytuuje trybunał kolegialny i następnie rozpoczyna

${ }^{4}$ Por. J. GręźLikowski, Procesy małżeńskie, w: Wielka Encyklopedia Prawa, t. II, Prawo kanoniczne, Warszawa 2014, s. 165.

${ }^{5}$ Por. kan. $1674 \$ 1$ KPK/MIDI.

${ }^{6}$ Por. kan. 1531 KPK.

${ }^{7}$ Por. kan. 1481-1482 KPK.

${ }^{8}$ Por. kan. 1672 KPK/MIDI. Zob. także A. BARTCZAK, Właściwość sądu w procesie zwykłym w ,Mitis Iudex Dominus Iesus, Ius Matrimoniale 28 (2017) nr 4, s. 29-44.

${ }^{9}$ Por. kan. 1676 KPK/MIDI w powiązaniu z kan. 1507-1513 KPK. 
się kolejna faza procesu - postępowanie dowodowe. Na tym etapie zbierany jest materiał dowodowy, który stanie się podstawą wyrokowania. Prawodawca przewidział w procesie o orzeczenie nieważności małżeństwa w sumie cztery możliwe do wykorzystania grupy środków dowodowych: oświadczenia stron, zeznania świadków, dokumenty, opinia biegłego. Po zebraniu materiału dowodowego trybunał przystępuje do publikacji akt. Przez publikację akt jako instytucję prawną należy rozumieć możliwość wglądu w akta upoważnionym przez prawo do tego osobom ${ }^{10}$, która służy zapoznaniu się ze zgromadzonym materiałem, jego oceną i możliwością podjęcia ewentualnych kolejnych kroków ${ }^{11}$. W przypadku, gdy strony nic więcej nie mają do dodania, postępowanie dowodowe zostaje zamknięte. Sprawa przechodzi w fazę dyskusji, w której kluczowe miejsce zajmują uwagi obrońcy węzła małżeńskiego. Stronom przysługuje prawo repliki. Następnie trybunał kolegialny wydaje wyrok. Tenże daje odpowiedź na pytanie postawione $\mathrm{w}$ formule zawiązania sporu. Następnie zostaje on ogłoszony stronom. Te zaś mają prawo odwołania się od

${ }^{10}$ Por. M.J. Arroba Conde, Diritto processuale canonico, Roma 2006, s. 493.

${ }^{11}$ Por. A. BArtczak, Ogłoszenie akt $w$ kanonicznym procesie małżeńskim, Annales Canonici 7 (2011), s. 244: ,Jak pokazuje rzeczywistość sądowa, strony korzystają z publikacji. W ten sposób zapoznają się ze wszystkimi dowodami przedstawionymi przez drugą stronę, począwszy od odpowiedzi na złożoną prośbę o stwierdzenie nieważności małżeństwa. Z uwagi na to, iż strony składają swoje oświadczenia oddzielnie, staje się możliwe zapoznanie z treścią przesłuchań. Także treści przesłuchań świadków spisane bez obecności stron procesowych zostają teraz podane do wiadomości. Prawem stron procesowych jest możliwość konfrontacji tego materiału z ich subiektywną oceną stanu wydarzeń podlegających badaniu w kontekście nieważności małżeństwa. Kiedy w procesie konieczne staje się powołanie biegłego sądowego celem wydania opinii, również jego opinia pozostaje do wglądu dla stron. Nadto wszystkie inne dokumenty przedstawiane przez strony, które stają się tym samym dowodami w sprawie zostają opublikowane stronom. Znając zatem ten cały materiał, stronom przysługuje prawo do wyjaśnień czy komentarzy. Z perspektywy dążenia do poznania prawdy w procesie, niezmiernie ważna staje się odpowiedź, gdy strony przedstawiają różne punkty widzenia. Konfrontacja różnych wypowiedzi może pobudzać do jeszcze większego zaangażowania się w budowanie przesłanek do powstania pewności moralnej u sędziów a w konsekwencji do poznania prawdy”. 
niego w formie apelacji lub skargi o nieważność wyroku. Gdy strony zgadzają się z wyrokiem, a stwierdza on nieważność małżeństwa, po upływie przewidzianych terminów, braku apelacji ze strony obrońcy węzła, wyrok staje się wykonalny ${ }^{12}$. W przeciwnym razie akta sprawy zostają przekazane trybunałowi II instancji.

\section{Cel procesu dokumentalnego i skróconego przed biskupem}

Proces zwyczajny, notabene jak sama nazwa wskazuje, jest podstawowym, standardowym procesem w sprawie orzeczenia nieważności małżeństwa. Oprócz niego orzec nieważność małżeństwa można w procesie dokumentalnym i skróconym. W zasadzie na tym zdaniu można by poprzestać, ale wydaje się, że jest zbyt ogólne stwierdzenie. Nie istniałyby różne procesy, gdyby nie było celu ich istnienia. Prawdą jest, że celem nadrzędnym jest sprawdzenie w toku stosownego postępowania czy małżeństwo zostało zawarte nieważnie. Za ważnością małżeństwa stoi bowiem domniemanie prawne zawarte w kan. 1060 KPK. Idzie więc o poznanie prawdy o danym małżeństwie. Jan Paweł II w jednym ze swoich przemówień do Roty Rzymskiej mówiąc o procesie małżeńskim podkreślał, że ,proces ten ze swej istoty jest nie do pomyślenia inaczej, jak tylko w kontekście dążenia do ustalenia prawdy ${ }^{13}$. Magisterium Kościoła w tym względzie jest zgodne a przy tym stanowcze. W procesie małżeńskim chodzi o prawdę obiektywną czyli veritas rei ${ }^{14}$. Sama zaś prawda obiektywna jest prawdą pełną, i to ją odróżnia od prawdy subiektywnej, która jest sądem o konkretnych faktach czy wydarzeniach postrzeganych przez osobę, podmiot.

Proces dokumentalny i proces skrócony oczywiście wpisują się w ten nadrzędny cel. Do niego de facto zmierzają, choć różnią się

\footnotetext{
${ }^{12}$ Por. kan. 1679 KPK/MIDI.

${ }^{13}$ Por. IoAnnes Paulus II, Ad Rotam Romanam habita (die 29.01.2004), AAS 96 (2004), s. 351.

${ }^{14}$ Zob. przemówienia papieskie do Trybunału Roty Rzymskiej: Piusa XII z 3.10.1941, AAS 33(1941), s. 421-426 a także z 1.10.1942, AAS 34 (1942), s. 338-342; Jana XXIII z 13.12.1961, AAS 53 (1961), s. 819; Jana Pawła II z 4.02.1980, AAS 72 (1980), s. 174-178 i z 28.01.1982, AAS 74 (1982), s. 449-454, a także z 25.01.1988, AAS (1988), s. 1178-1185 i z 28.01.1994, AAS 86 (1994), s. 947-952.
} 
przede wszystkim środkami, którymi posługują się, aby ten cel osiągnąć. Proces dokumentalny i skrócony przed biskupem swoje źródło mają w zmianach, odejściach od formuły podstawowej (procesu zwyczajnego) ze względu na uproszczenie formy. O tym jednak zostanie szczegółowo powiedziane w kolejnym punkcie. Proces dokumentalny jest procesem, który ma zastosowanie, gdy strona (strony) chce udowodnić nieważność małżeństwa $\mathrm{z}$ powodu istniejącej $\mathrm{w}$ momencie zawierania małżeństwa przeszkody małżeńskiej lub braku przewidzianej prawem formy. Centralne miejsce tego procesu zajmuje dokument. Prawodawca używa w tekście na określenie dokumentu słowa documentum, które oznacza dowód, świadectwo ${ }^{15}$. Doktryna podaje, iż dokument można rozumieć dwojako. Sensu largo jest nim każdy nośnik informacji o faktach istotnych dla sprawy (fotografie, taśmy magnetofonowe, kasety wideo, dane nagrane na dyskach komputerowych, na pamięciach przenośnych). Sensu stricto dokumentem jest przedmiot, najczęściej papier, pokryty pismem wyrażającym oświadczenie, myśl, opis, ślad działalności prawnej ${ }^{16}$.

Dokument w świetle kan. 1688 KPK winien być bezsporny i niepodważalny: „(...) może orzec wyrokiem nieważność małżeństwa, jeżeli z dokumentu, który nie podlega żadnemu sprzeciwowi lub zarzutowi, wynika w sposób pewny istnienie przeszkody zrywającej lub brak przepisanej prawem formy". W tym sensie co do zasady podstawą procesu dokumentalnego staje się dokument urzędowy, albowiem zgodnie z kan. $1541 \mathrm{KPK}$,,publiczne dokumenty mają moc dowodową we wszystkim, co się w nich stwierdza wprost i zasadniczo"17.

\footnotetext{
${ }^{15}$ Por. Słownik łacińsko-polski, t. 1, red. J. Korpanty, Warszawa 2001, s. 596.

16 Por. A. BARTCZAK, Dokument jako środek dowodowy w procesie małżeńskim, Łódzkie Studia Teologiczne 22 (2013), s. 6; M. Sitarz, Słownik prawa kanonicznego, Warszawa 2004, kol. 42. Por. A. SoBCzAK, Stwierdzenie nieważności małżeństwa i inne małżeńskie procesy kościelne, Poznań 2010, s. 106, W. Witkowski, Natura i moc dowodowa dokumentu w kanonicznym procesie sądowym, Lublin 2018.

17 Por. W. Wiткоwsкi, Dawne i obecne umocowanie prawne procesu dokumentalnego, Kościół i Prawo 6 (19) 2017, nr 2, s. 212: „Zazwyczaj mają tu zastosowanie urzędowe zaświadczenia proboszcza parafii, w której przeprowadzono dochodzenie przedślubne i zawarto małżeństwo, że podczas zawierania małżeństwa istniała
} 
Proces skrócony przed biskupem stał się swoistą odpowiedzią na lukę jaka dotychczas istniała co do zastosowania skróconej wersji procesu de nullitatae, gdy mowa jest o wadzie zgody jako potencjalnej przyczynie nieważności małżeństwa. Celem zatem tego procesu staje się odkrycie prawdy o małżeństwie w świetle orzeczenia nieważności małżeństwa w oparciu o kan. 1095-1103 KPK. Bez wątpienia Prawodawca podjął się odważnie bardzo trudnej kwestii. Jest ona wynikiem obserwacji papieża Franciszka współczesnych problemów dotykających rodzinę czy wreszcie konkretnego człowieka. O usprawnienie kanonicznych procesów małżeńskich wraz z wprowadzeniem nowej formuły w sprawach oczywistych wypowiadali się już ojcowie synodalni ${ }^{18}$. Pokłosiem wysuwanych przez nich propozycji stała się nowelizacja Mitis Iudex Dominus Iesus, w której papież Franciszek podkreślił, iż „troska o zbawienie dusz pozostaje najwyższym celem instytucji, ustaw i prawa"19. Warto mocno podkreślić słowa Franciszka, że powyższa reforma nie ma na celu promowania nieważności małżeństwa, pomimo że początkowo mocno było słychać tego typu głosy! ${ }^{20}$ Bez wątpienia argumentem papieża przeciw takim sugestiom jest fakt, że stawia on biskupa diecezjalnego w roli sędziego a jednocześnie gwaranta katolickiej jedności z Piotrem w wierze i dyscyplinie ${ }^{21}$.

przeszkoda zrywająca i nie udzielono dyspensy lub że nie zachowano właściwej formy kanonicznej. W archiwum parafialnym powinno znajdować się pełnomocnictwo, którego ważność może być kwestionowana w procesie dokumentalnym. $\mathrm{W}$ procesach tych są brane pod uwagę również zaświadczenia wystawiane przez kurie diecezjalne, np. o udzieleniu lub nieudzieleniu dyspensy od przeszkody zrywającej".

${ }^{18}$ Por. Relatio Synodi III Nadzwyczajnego Zgromadzenia Ogólnego Synodu Biskupów: „Wyzwania duszpasterskie dla rodziny w kontekście nowej ewangelizacji”, n. 48, w: http://bit.ly/pk2019-3-2 [dostęp 18.08.2019]

${ }^{19}$ Por. Franciszek, List apostolski motu proprio „Mitis Iudex Dominus Iesus”, reformujący kanony Kodeksu Prawa Kanonicznego dotyczące spraw o orzeczenie nieważności małżeństwa (tekst łacińsko-polski), Tarnów 2015, s. 9.

${ }^{20}$ Tamże.

${ }^{21}$ Tamże, s. 13. 
Zatem zarówno proces dokumentalny jak i zwłaszcza proces skrócony wpisują się w cel reformy prawa, jakim jest przede wszystkim usprawnienie procedury orzekania ${ }^{22}$.

\section{Forma procesu dokumentalnego i skróconego przed biskupem}

Jak zostało zatem przedstawione powyżej zarówno proces dokumentalny, a także skrócony przed biskupem zmierzają zasadniczo w jednym kierunku. Sposób jednak dojścia do tego celu jest różny. Wynika on bowiem $\mathrm{z}$ różnorodności dróg prawnych, to jest innych przepisów procesowych. I tak odpowiednio przepisy dotyczące procesu dokumentalnego Prawodawca zamieścił w znowelizowanych kan. 1688-1690 KPK, a procesu skróconego przed biskupem w kan. 1683-1687 KPK. Prześledźmy ten proces analizując poszczególne fazy.

\subsection{Skarga powodowa}

W przepisach dotyczących procesu dokumentalnego Prawodawca nie wskazuje wymogów dotyczących skargi powodowej. Brak prawa w tym zakresie oznacza, że zastosowanie mają przepisy kan. 1504 KPK oraz art. 116-117 DC. Zgodnie z nimi skarga powodowa powinna wyrażać, wobec jakiego sądu sprawa jest wnoszona, określać przedmiot sporu, czyli wskazywać o jakie małżeństwo chodzi a także podstawy skargi, czyli tytuł lub tytuły prawne nieważności. Skarga powinna być uzasadniona, czyli winna wskazywać, przynajmniej ogólnie, fakty i dowody, na których opiera się żądanie. W skardze należy zamieścić informację dotyczącą stałego lub tymczasowego miejsca zamieszkania drugiego małżonka. Nadto skarga powinna być podpisana przez stronę powodową lub jego pełnomocnika, ze wskazaniem daty oraz miejsca zamieszkania strony powodowej. Do samej skargi, jak wskazuje Prawodawca, powinien być dołączony autentyczny egzemplarz świadectwa zawartego małżeństwa oraz

\footnotetext{
${ }^{22}$ Por. P. Majer, Art. 5/Tytuł V-Proces małżeński skrócony przed biskupem, w: Praktyczny komentarz do Listu apostolskiego Mitis Iudex Dominus Iesus papieża Franciszka, red. P. Skonieczny, Tarnów 2015, s. 163-164.
} 
dokument o stanie cywilnym ${ }^{23}$. Dodatkowo ze względu na rodzaj procesu, Prawodawca żąda, o ile to możliwe, aby do skargi dołączyć dokument lub dokumenty, które stanowią podstawę żądania procesu dokumentalnego. Ten dokument winien być autentyczny i niepodważalny ${ }^{24}$. Ilekroć idzie o ten proces, który zmierza do orzeczenia nieważności małżeństwa na skutek istniejącej przeszkody zrywającej lub braku formy kanonicznej albo wadliwego pełnomocnictwa, Prawodawca zasadniczo wymaga dokumentu urzędowego ${ }^{25}$, nie wykluczając oczywiście dokumentu prywatnego. Podkreślam dokument publiczny, bo w przeważającej większości przeszkód obalenie domniemania ważności małżeństwa może nastąpić właśnie przez wykazanie tego rodzaju dokumentu. Ponadto w przypadku przeszkód z prawa kościelnego potrzebnym dokumentem urzędowym będzie informacja o braku udzielenia dyspensy od przeszkody przez Stolicę Apostolską lub ordynariusza miejsca. Ponadto zgodnie z kan. 1081 KPK Ustawodawca nakłada obowiązek powiadomienia o fakcie udzielenia dyspensy w zakresie zewnętrznym ordynariusza miejsca, zarówno w przypadku niebezpieczeństwa śmierci jak i wypadku naglącym. Gdyby zaś udzielono dyspensy w zakresie wewnętrznym niesakramentalnym od przeszkody tajnej, jeśli czego innego nie postanawia reskrypt Penitencjarii, to powinna być ona wpisana do księgi przechowywanej w tajnym archiwum kurii ${ }^{26}$.

\footnotetext{
${ }^{23}$ Por. H. Stawniak, Komentarz do art. 116 DC, w: Komentarz do Instrukcji procesowej „Dignitas connubii”, red. T. Rozkrut, Sandomierz 2007, s. 183: „Te dokumenty pozwalają bowiem sądowi zorientować się o aktualnym statusie cywilnym stron (rozwiedzeni, samotni, żyjący w nowym związku cywilnym).

${ }^{24}$ Por. art. $297 \$ 1$ DC: „Ponieważ bardzo rzadko przeszkoda impotencji czy braku formy prawnej mogą wynikać $z$ dokumentu niepodlegającego żadnemu zarzutowi czy sprzeciwowi, wikariusz sądowy lub wyznaczony sędzia winien w tych przypadkach przy wstępnym badaniu postępować ze szczególną dokładnością, żeby sprawa nie została dopuszczona zbyt łatwo i nierozważnie do procesu opartego na dokumentach".

${ }^{25}$ Por. M. Greszata, Komentarz do art. 295 DC, w: Komentarz do Instrukcji procesowej „Dignitas connubii”, red. T. Rozkrut, Sandomierz 2007, s. 394.

${ }^{26}$ Por. kan. 1082 KPK; W. Góralski, Przeszkody małżeńskie w ogólności, w: Przeszkody małżeńskie w prawie kanonicznym, red. W. Góralski, Warszawa 2016, s. 59:
} 
W przypadku procesu skróconego przed biskupem, Prawodawca w kan. 1684 KPK wskazuje: „Skarga powodowa, która rozpoczyna proces skrócony, oprócz tego co jest wymienione w kan. 1504, winna: $1^{\circ}$ przedstawiać krótko, całościowo i jasno fakty, na których opiera się żądanie; $2^{\circ}$ wskazać dowody, które mogłyby być natychmiast zebrane przez sędziego; $3^{\circ}$ zawierać w załączeniu dokumenty, na których opiera się żądanie”. Podobnie zatem jak w przypadku procesu dokumentalnego podstawą wymogów formalnych jest kan. 1504 KPK. Ta norma zostaje jedynie uzupełniona tym kanonem. Po pierwsze Prawodawca żąda od skargi przeznaczonej do procesu skróconego zwięzłości a jednocześnie klarowności. To ewidentnie koresponduje z samym założeniem i celem tego procesu. Można by rzec, że w tej skardze nie liczy się jedynie ogólne przedstawienie faktów, jak byłoby to zgodnie z kan. 1504 KPK i art. 116 DC, ale konkret, czyli wskazanie wprost defektu oświadczenia woli. Z drugiej zaś strony jak podkreśla P. Majer, nie ma podstaw prawnych do odrzucenia prośby, która byłaby opisana zbyt ogólnie i obszernie, o ile oczywiście przytacza fakty i dowody na poparcie żądania ${ }^{27}$. Należy się z tym zdaniem zgodzić, albowiem na etapie składania prośby o orzeczenie nieważności małżeństwa, nie jest określone czy definitywnie sprawa będzie rozstrzygana w trybie procesu skróconego czy zwykłego. To rozstrzygnie się dopiero w dekrecie zawiązania sporu. Po drugie skarga winna wskazy wać na dowody, które po prostu są, tzn. nie potrzeba czasu na ich zebranie. W związku z tym Prawodawca w punkcie trzecim wskazuje, że do skargi winny być dołączone także dokumenty, na których opiera się żądanie. Te dokumenty mają uwiarygodnić tezę stron o nieważności małżeństwa. Wydaje się jednak, że nie są one obligatoryjne do prowadzenia procesu, a tym samym ich brak nie może stanowić

\footnotetext{
„Nie należy zatem powiadamiać ordynariusza miejsca ani dokonywać żadnej adnotacji o udzieleniu dyspensy przez spowiednika w zakresie wewnętrznym sakramentalnym. Tego rodzaju akt ma więc znaczenie jedynie na tym właśnie forum. Stąd też, jeśli przeszkoda, od której spowiednik udzielił w ten sposób dyspensy, stałaby się następnie publiczną, należałoby uzyskać nową, ważną pro foro externo".

${ }^{27}$ Por. P. MAJER, dz. cyt., s. 171-172.
} 
podstawy odrzucenia prośby o nieważność małżeństwa. Albowiem w kan. 1683, $2^{\circ}$ KPK czytamy: „Jedynie do biskupa diecezjalnego należy orzekanie w sprawach o nieważność małżeństwa w procesie skróconym, ilekroć przytaczane są okoliczności dotyczące faktów lub osób, poparte zeznaniami lub dokumentami (testimoniis vel instrumentis)". Bez wątpienia stanowią one mocny dowód w procesie, ale jedynie w świetle tych tytułów, które można udowodnić takowym dowodem. W Ratio procedendi w art. $14 \$ 2$ została zamieszczona jedynie informacja, iż do dokumentów, które uzasadniają wniosek, należy każdy dokument medyczny, który w sposób oczywisty wyklucza konieczność zasięgnięcia opinii biegłego z urzędu. Opinia zaś z urzędu wymagana jest przez Prawodawcę zgodnie z kan. 1678 $\$ 3 \mathrm{KPK}$ w sprawach dotyczących m.in. braku zgody spowodowanej chorobą umysłową lub anomalią natury psychicznej.

\subsection{Czynności wstępne}

Charakterystyczne dla procesów skróconych, zarówno dokumentalnego jak i przed biskupem, jest maksymalne uproszczenie samych czynności procesowych jak i ich zakresu. W procesie dokumentalnym zgodnie z kan. 1688 KPK podkreśla się pominięcie formalności procesu zwykłego przed zasadniczo podjęciem decyzji (wyroku) ${ }^{28}$. Kiedy skarga powodowa trafia do sądu, pierwszą czynnością wikariusza sądowego jest sprawdzenie swojej właściwości. Jeśli skarga nie zawiera błędów formalnych i merytorycznych zostaje formalnie dekretem przyjęta. W dekrecie tym oficjał wyznacza obrońcę węzła, o czym następnie informuje strony i samego obrońcę węzła małżeńskiego. Następnie przekazuje skargę obrońcy i stronie pozwanej, wyznaczając jej termin 15 dni na ustosunkowanie ${ }^{29}$.

W procesie skróconym przed biskupem podobnie jak i w procesie zwykłym jak i dokumentalnym wikariusz sądowy powinien zbadać skargę powodową od strony formalnej jak i merytorycznej $\mathrm{z}$ naciskiem na wymogi dotyczące procesu skróconego zgodnie z kan.

\footnotetext{
${ }^{28}$ Por. art. 295 DC.

${ }^{29}$ Por. kan. 1676 KPK/MIDI.
} 
1683-1684 KPK. Warto podkreślać normę płynącą z kan. 1675 KPK, która jakkolwiek odnosi się do każdego procesu małżeńskiego, ale szczególnego wydźwięku nabiera właśnie w procesie skróconym przed biskupem: „Sędzia przed przyjęciem sprawy winien mieć pewność, że małżeństwo rozpadło się w sposób nieodwracalny, tak iż nie ma możliwości wznowienia wspólnoty życia małżeńskiego". Niewątpliwie $\mathrm{w}$ procesie skróconym wikariusz sądowy musi zmierzyć się z wiele trudniejszą oceną strony merytorycznej skargi powodowej, którą docelowo ma przedstawić przecież biskupowi diecezjalnemu. Kiedy skarga spełnia wymogi i jest podpisana przez obojga małżonków, powinien skargę formalnie przyjąć. Zobowiązany jest tym samym przekazać odpis skargi obrońcy węzła małżeńskiego, którego powołuje w tym samym dekrecie. Zgodnie z wytycznymi Ratio procedendi w art. 15 należy uwzględnić, iż ,Jeżeli została przedłożona skarga powodowa w celu rozpoczęcia procesu zwykłego, jednak wikariusz sądowy uważa, że może ona zostać rozpoznana w procesie skróconym, powinien on wraz z notyfikacją skargi, zgodnie z kan. $1676 \$ 1$, stronie pozwanej, która jej nie podpisała, równocześnie poprosić ją o poinformowanie sądu, czy zamierza przyłączyć się do przedstawionego żądania i uczestniczyć w procesie. Ilekroć to konieczne, wikariusz sądowy poprosi stronę lub strony, które podpisały skargę, o jak najszybsze jej uzupełnienie zgodnie z kan. 1684". W tej sytuacji musi zaczekać na udzielenie odpowiedzi. Brak odpowiedzi strony pozwanej zgodnie z kan. $1676 \$ 2$ KPK, będzie skutkował uznaniem strony za nieobecną ${ }^{30}$. Po spełnieniu tych kroków wikariusz sądowy może wystawić dekret zawiązania sporu.

\subsection{Zawiązanie sporu i wybór trybu procesu}

Punktem wyjścia dla każdego procesu jest etap zawiązania sporu. W nim bowiem zostaje określona formuła wątpliwości, na którą

\footnotetext{
${ }^{30}$ Por. W. Gór ALski, Proces małżeński skrócony przed biskupem, Płock 2017, s. 106: „Nie trzeba wspominać, że milczenie strony pozwanej, podobnie jak jej zdanie się na sprawiedliwość sądu, nie może być uznane za przyłączenie się do prośby strony powodowej o proces skrócony".
} 
odpowiedź ma dać wyrok. Oczywiście formuła ta przyjmuje postać pytania czy zaskarżone małżeństwo zostało zawarte nieważnie z tytułu lub tytułów. W przypadku procesu dokumentalnego, o czym była już mowa, tytuły dotyczyć będą przeszkody małżeńskiej, braku przepisanej prawem formy kanonicznej a także braków lub wad dotyczących pełnomocnictwa do zawarcia małżeństwa. W procesie dokumentalnym najczęściej zaskarżane będzie małżeństwo z jednego tytułu, choć nie ma formalnych przeciwwskazań na prowadzenie sprawy z kilku tytułów. Ta kwestia wygląda zupełnie inaczej w procesie skróconym przed biskupem. W doktrynie sugeruje się wręcz, żeby formuła wątpliwości w takim procesie uwzględniała tylko jeden tytuł nieważności, ten co do którego na bazie pozwu oraz przedłożonych dowodów można już na tym etapie mówić o pewności ${ }^{31}$. Oczywiście ta interpretacja dowodów podlega swobodnej ocenie wikariusza sądowego. Analizując obydwa procesy należy podkreślić wspólny mianownik. Po upływie czasu na udzielenie odpowiedzi, lub jeśli jest to konieczne po ponownym wezwaniu drugiej strony, wikariusz sądowy wydaje kolejny dekret dotyczący ustalenia formuły wątpliwości. Jeśli wcześniej strona pozwana nie wyraziła zgody na proces, przysługuje jej 10 dniowy termin na ewentualne odwołanie. W tymże samym dekrecie wikariusz sądowy podejmuje kluczową decyzję. Ustala on tryb procesu. Jakkolwiek wybór procesu dokumentalnego nie nastręcza większych trudności oficjałowi, tak wybór procesu skróconego obarczony jest dużą odpowiedzialnością. Słusznie zauważa M. Greszata-Telusiewicz, iż kryterium oczywistości wprowadzone w kan. $1683,1^{\circ} \mathrm{KPK}$ jest niezwykle trudne do zweryfikowania, choć w rzeczy samej to kryterium miało usprawnić i uprościć procedurę ${ }^{32}$. Niemniej wikariusz sądowy podejmując decyzję o procesie skróconym przed biskupem wyznacza jednocześnie instruktora i asesora. Zgodnie z art. 16 Ratio procedendi wikariusz sądowy może wyznaczyć

\footnotetext{
${ }^{31}$ Por. M. Greszata-Telusiewicz, Processus brevior, w: Proces małżeński według motu proprio Mitis Iudex Dominus Iesus, red. J. Krajczyński, Płock 2015, s. 82; P. Majer, dz. cyt., s. 176.

${ }^{32}$ Por. M. Greszata-Telusiewicz, Processus..., dz. cyt., s. 80.
} 
siebie samego jako instruktora, ale również może wskazać na kogoś innego ${ }^{33}$.

\subsection{Faza dowodowa}

Proces dokumentalny ma to do siebie, że punkt centralny fazy dowodowej stanowi odpowiedni dokument. Ma on, zgodnie z przyjętym kryterium dawać świadectwo czegoś, być dowodem czegoś ${ }^{34}$. Zgodnie z kan. 1688 KPK, wyznaczony do sprawy sędzia winien pomijając formalności procesu zwykłego wezwać strony procesowe z udziałem obrońcy węzła małżeńskiego. Składane zeznania stron a także ewentualnie świadków w tym procesie mają charakter jedynie uzupełniający. Po zebraniu materiału dowodowego Prawodawca nie przewiduje publikacji akt, albowiem strony wcześniej już zapoznały się z dokumentem, który stanowi główny dowód w sprawie.

W procesie skróconym przed biskupem po zawiązaniu sporu wikariusz sądowy wzywa wszystkich, którzy powinni wziąć udział, na posiedzenie, które winno odbyć się w ciągu trzydziestu dni ${ }^{35}$. Prawodawca wskazuje więc, że na to posiedzenie winni stawić się zainteresowani procesem oraz powołani do tego procesu, $\mathrm{tj}$. instruktor, asesor, obrońca węzła małżeńskiego, notariusz, strony procesowe, ewentualni świadkowie. Instruktor winien zebrać dowody, o ile to możliwe, podczas jednego posiedzenia ${ }^{36}$. Jednocześnie należy podkreślić, iż w wezwaniu do sądu, strony winny zostać poinformowane o tym, że nie później niż na trzy dni przed posiedzeniem dowodowym mogą złożyć propozycje kwestii niezałączonych do skargi powodowej, co do których proszą o przesłuchanie stron lub świadków ${ }^{37}$. Dodatkowo zostało zaznaczone w Ratio procedendi, iż strony oraz ich adwokaci mogą uczestniczyć w przesłuchaniu drugiej strony oraz

\footnotetext{
${ }^{33}$ Por. Trybunae Apostolski Roty Rzymskiej, Subsydium aplikacyjne do Motu pr. Mitis Iudex Dominus Iesus, s. 39, w: http://www.rotaromana.va/content/dam/ rotaromana/documenti/Sussidio/Subsidium\%2c\%20polacco.pdf [dostęp 18.08.2019].

${ }^{34}$ Por. Słownik łacińsko-polski, t. 1, red. J. Korpanty, Warszawa 2001, s. 596.

${ }^{35}$ Por. kan. 1685 KPK/MIDI.

${ }^{36}$ Por. kan. 1686 KPK/MIDI.

${ }^{37}$ Por. art. 17 Zasad proceduralnych.
} 
świadków, chyba że instruktor uważa, że ze względu na okoliczności rzeczowe i osobowe należy postąpić inaczej. Wszelkie odpowiedzi stron a także świadków notariusz ma zredagować w formie pisemnej, sumarycznie i w tym tylko, co należy do istoty małżeństwa będącego przedmiotem sporu ${ }^{38}$.

To co łączy te dwa tryby procesowe to oczywiście skrócenie do maksimum fazy dowodowej. W zasadzie mowa jest o wezwaniu stron, a więc złożeniu przez nie zeznań w procesie dokumentalnym oraz o zasadniczo jednym posiedzeniu, na którym będą przedstawione i zebrane wszystkie dowody. Nie jest to jednak tożsame z konfrontacją, którą prawo przewiduje, choć i jej się nie wyklucza. Zarówno w procesie dokumentalnym jak i skróconym przed biskupem, Prawodawca nie przewidział publikacji akt. Niewątpliwie związane jest to $z$ efektem całego procesu dowodowego, co zostało zresztą przedstawione.

Powyższe normy i zasady wskazują na kilka różnic w świetle procesu dokumentalnego. Po pierwsze w procesie skróconym podkreślone zostało jedno posiedzenie, na które wzywa się wszystkich zainteresowanych. W procesie dokumentalnym zasadniczo nie wzywa się świadków, chyba że idzie o świadka kwalifikowanego, którego zeznania wprost odnoszą się do sprawy, np. w przypadku braku formy. Po drugie, Prawodawca określa termin zwołania posiedzenia. Nie jest to co prawda termin zawity z przekroczeniem, którego związane byłyby jakieś sankcje procesowe, niemniej jego przekroczenie jest wystąpieniem przeciwko samej idei processus brevior ${ }^{39}$. Takiej normy Prawodawca nie zamieszcza w stosunku do procesu dokumentalnego, pozostawiając swobodę ustalenia terminu sędziemu.

\subsection{Faza dyskusji}

$\mathrm{W}$ procesie dokumentalnym zasadniczo nie jest przewidziana dyskusja sprawy. Wynika to oczywiście ze specyfiki procesu. W procesie skróconym przed biskupem, instruktor po przeprowadzonym posiedzeniu, ma obowiązek wyznaczyć termin piętnastu dni na

\footnotetext{
${ }^{38}$ Por. art. 18 tamże.

${ }^{39}$ Por. P. MAjer, dz. cyt., s. 179.
} 
przedstawienie uwag na korzyść węzła oraz wniosków obrończych stron, o ile takowe w ogóle są zgłaszane. P. Bianchi zauważa, że termin ten jest krótki i mogą pojawić się trudności z jego przestrzeganiem. Niemniej należy starać się go dotrzymać, a w sytuacjach wyjątkowych można prosić o jego wydłużenie ${ }^{40}$. Niemniej, bez względu na proces, na tym etapie zaznacza wymiernie swoją obecność obrońca węzła małżeńskiego. Jego zadaniem, podobnie jak w procesie zwykłym, jest przedstawienie uwag przedwyrokowych. Animadversiones nabierają szczególnej wagi zwłaszcza w processus brevior ze względu na charakter procesu. Obrońca staje się przeciwwagą dla twierdzeń stron, które jednogłośnie zwracają się o stwierdzenie nieważności małżeństwa. I choć w procesie dokumentalnym trudniej jest znaleźć argumenty przeciw nieważności to w procesie skróconym przed biskupem niekoniecznie musimy mieć do czynienia $z$ dowodami w postaci dokumentów potwierdzających tezę stron. Uwagi, ze względu na charakter procesów powinny być zwięzłe, syntetyczne, przejrzyste ${ }^{41}$. Obrońca zdecydowanie bierze czynny udział w poszukiwaniu prawdy

\footnotetext{
${ }^{40}$ Por. kan. 1686 KPK/MIDI.

${ }^{41}$ Por. P. Bianchi, Lo svolgimento del processo breve: la fase istruttoria e di discussione della causa, w: La riforma di processi matrimoniali di Papa Francesco. Una guida per tutti, red. Redazione di Quaderni di diritto ecclesiale, Milano 2016, s. 87: , Ci si potrebbe altresì domandare se quello di quindici giorni sia davvero un termine realistico. Ciò sia in relazione alla complessità delle cause matrimoniali, sia al carico di lavoro che gli avvocati e i difensori del vincolo potrebbero avere e che potrebbe ostacolare - anche senza loro colpa - l'approntamento di una difesa davvero efficace in un termine così breve. In questa fase iniziale penso sia giusto provare a impegnarsi a rispettare il più possibile questo termine, magari lasciandosi ispirare dai sapienti suggerimenti di DC $254 \$ 1$ per la redazione della sentenza, che possono però certamente essere applicati anche alle osservazioni della parte pubblica e alle memorie delle parti: sinteticità, perspicuità, aderenza al tema di causa possono essere dei criteri utili per rispettare un termine così impegnativo quale quello fissato dal can. 1686 MIDI. In caso di giustificata difficoltà a rispettarlo, sarà sempre possible chiederne una proroga, che l'istruttore non mancherà di valutare nelle sue ragioni ed eventualmente accordare senza dilazionare troppo il passaggio alla fase successiva del processo".
} 
o małżeństwie i bezwzględnie przyczynia się do wyrobienia opinii o małżeństwie przez biskupa diecezjalnego.

W fazie dyskusji zasadniczo repliki nie są zabronione. $Z$ jednej jednak strony nie są one wyraźnie przewidziane. Ekonomia procesu skłaniałaby się w stronę, aby uznać je za niekwalifikujące się, bo faktycznie co może przynieść dla sprawy taka dyskusja na tym etapie? Oczywiście, o ile instruktor uzna to za pożyteczne, może dopuścić do takiej wymiany argumentów ${ }^{42}$.

\section{Sędzia w procesie}

Nie ulega wątpliwości, iż władnym wydania decyzji w procesie kanonicznym jest sędzia. Pierwszym sędzią dla wszystkich spraw, wprost przez prawo nie wyjętych, w diecezji jest biskup diecezjalny. Ten może swój urząd wypełniać osobiście albo przez innych ${ }^{43}$. Do tego zaś celu winien ustanowić sędziów. Na tym zatem poziomie mamy do czynienia ze zgodnością w kontekście analizowanego problemu. Więcej, zarówno jeden jak i drugi proces, ze względu na swoją specjalność, został wskazany jako forma skrócona. Zakłada więc już u swego źródła pewną łatwość w podjęciu decyzji, brak skomplikowanej sytuacji, stanu faktycznego. Wobec powyższego Prawodawca zlecił osąd w tym procesie jednemu sędziemu, a nie jak w przypadku procesu zwykłego kolegium sędziowskiemu ${ }^{44}$.

Jednakże należy też wykazać różnice. W procesie dokumentalnym sędzią może być zarówno biskup diecezjalny lub wikariusz sądowy lub wyznaczony sędzia. Wszystko zależy wpierw od decyzji biskupa diecezjalnego, który ma prawo zastrzec sobie daną sprawę lub zakres spraw do sądzenia. Jeśli tego nie zrobił, kompetentnym do prowadzenia tego typu procesu staje się wikariusz sądowy. Jednakże i on nie ma obowiązku prowadzenia takiego procesu, albowiem może wyznaczyć innego sędziego ustanowionego przez biskupa diecezjalnego jako sędziego w trybunale.

\footnotetext{
${ }^{42}$ Tamże.

${ }^{43}$ Por. kan. $1419 \$ 1$ KPK.

${ }^{44}$ Por. kan. 1683 i 1688 KPK/MIDI do $1676 \S 3$ KPK/MIDI.
} 
Inaczej ma się rzecz w procesie skróconym przed biskupem. Nie ma możliwości wyboru sędziego w procesie skróconym. Jak sama nazwa i założenie samego procesu wskazują, mamy do czynienia z procesem skróconym coram episcopo. Jedynie biskup diecezjalny jest kompetentny do prowadzenia tego procesu i w konsekwencji wydania wyroku. Owszem, biskup może odmówić rozpoznania sprawy w tym trybie. Jednakże konsekwencją staje się przekazanie sprawy do procesu zwykłego, z zachowaniem możliwości odwołania się od dekretu odrzucenia skargi ${ }^{45}$. W sposób szczególny akcentuje się i podkreśla, iż jedynie biskup diecezjalny jest sędzią w tym procesie. Nikt nie może go zastąpić. W przypadku wakatu na urzędzie biskupa diecezjalnego nie ma podmiotu, który mógłby zastąpić biskupa diecezjalnego. Nawet wikariusz sądowy, który nie traci swojego urzędu, nie ma prawa wyrokować w takich procesach. Osoba biskupa diecezjalnego jest w tym względzie niezastąpiona. W przypadku zatem, kiedy małżonkowie prosiliby o posługę w procesie skróconym, wikariusz sądowy kieruje sprawę do rozpatrzenia w procesie zwykłym ${ }^{46}$.

Konstatując należy powiedzieć, iż biskup każdorazowo może być sędzią zarówno w jednym jak i drugim procesie, natomiast pozostali sędziowie, mogą sprawować swój urząd tylko w procesie dokumentalnym.

\section{Decyzja sędziego}

Decyzję sędziego należy rozumieć w dwojaki sposób. Po pierwsze w znaczeniu pragmatycznym jest procesem podjęcia wysiłku szczegółowego przeanalizowania materiału dowodowego, który ukazuje stan faktyczny. Zestawia on fakty z prawem a także swoją wiedzą i doświadczeniem. Dokonuje się w ten sposób proces dochodzenia do pewności moralnej. Jest ona wymagana do podjęcia wyroku. Jak zauważa Z. Grocholewski na drogę do osiągnięcia pewności moralnej składają się: cechy osobowościowe sędziego i jego przygotowanie,

\footnotetext{
${ }^{45}$ Por. P. MAJER, dz. cyt., s. 174-175.

${ }^{46}$ Por. P.V. Pinto, Małżeństwo i rodzina na synodalnej ścieżce papieża Franciszka. Papieska sentencja procesu skróconego, Città del Vaticano, 2019, s. 189.
} 
obowiązek zachowania prawa procesowego a także wysiłek oceniania dowodów według swego sumienia ${ }^{47}$. Zgodnie z kan. $1608 \$ 4$ KPK, sędzia, który nie może osiągnąć takiej pewności, powinien orzec, że nie udowodniono uprawnienia powoda.

Zestawienie obydwu procesów, dokumentalnego i skróconego przed biskupem, prowadzi jednak do wykazania istotnych różnic dotyczących samej decyzji i w zasadzie jej konsekwencji. W procesie dokumentalnym sędzia stosując wyżej wymienione kryteria dochodzi lub nie do pewności moralnej. Wiąże się to więc z wydaniem decyzji o nieważności małżeństwa lub stwierdzeniem, że małżeństwo należy uważać nadal za ważne i prawnie obowiązujące. Zatem wyrok sędziego jednoosobowego w procesie dokumentalnym jest ostatnią czynnością konwencjonalną podjętą przez sędziego w toku procesu na szczeblu określonej instancji. Na tym jego działalność się kończy. Oczywiście należy pamiętać zgodnie z kan. $1689 \$ 2$ KPK/MIDI, że nienaruszone pozostaje prawo do apelacji strony, która czuje się pokrzywdzona decyzją, a także obrońcy węzła małżeńskiego. W przypadku, gdy taka apelacja nie zostanie wniesiona w przewidzianych prawem terminach zawitych, wyrok staje się prawomocny.

Zupełnie inaczej wygląda decyzja biskupa w procesie skróconym. Biskup diecezjalny, jako sędzia, dokonuje analizy materiału dowodowego. Słusznie zauważa P.V. Pinto, iż „odpowiedzialność za takiego rodzaju decyzje spada wyłącznie na biskupa. Jeżeli biskup ograniczyłby się tyko do podpisania gotowej sentencji - popadlibyśmy w jeszcze większy formalizm i w absurdalny fenomen delegacji sumienia ${ }^{48}$. Jeśli uzyska pewność moralną, podobnie jak każdy sędzia, powinien wydać wyrok stwierdzający nieważność małżeństwa. Jeśli jednak w swoim procesie wyrokowania nie osiągnie pewności moralnej - nie wydaje wyroku! Sprawa zatem nie jest zakończona.

\footnotetext{
${ }^{47}$ Por. Z. Grocholewski, Pewność moralna jako klucz do lektury norm procesowych, Ius Matrimoniale 3 (1998), s. 32-39; kan. $1608 \$ 1-3$ KPK, art. 247 DC, art. 12 Ratio.

${ }^{48}$ Por. P.V. Pinto, dz. cyt., s. 203.
} 
Zgodnie $\mathrm{z}$ kan. 1687 \$1 KPK/MIDI biskup powinien przekazać sprawę do procesu zwykłego ${ }^{49}$.

Można więc zatem stawiać pytanie: czy sędzia może nie wydać decyzji w rozpatrywanej sprawie? Dlaczego biskup, tak jak każdy sędzia w zwykłym procesie małżeńskim, nie osiągnąwszy pewności moralnej, nie może wydać decyzji non constare de nullitatae matrimonii? Taka sytuacja wzbudziła w środowisku kanonistów wiele dyskusji, wątpliwości i obaw. Należy pamiętać, iż biskup bierze w procesie udział w poszukiwaniu prawdy. W komentarzach dominuje jednak tendencja do usprawiedliwienia, a może wyjaśnienia, poprawnego interpretowania takiej sytuacji. Wskazuje się szczególnie na aspekt duszpasterski, który nie przekreśla pragnienia stron o stwierdzenie nieważności ich małżeństwa, w sytuacji, gdy szybko zebrany, podstawowy materiał dowodowy nie dał biskupowi przekonania o nieważności ${ }^{50}$. Należy jednak z drugiej strony pamiętać, iż jedną z przesłanek do prowadzenia procesu skróconego jest wszak „przytoczenie okoliczności dotyczących faktów lub osób, poparte zeznaniami lub dokumentami, które nie wymagają przeprowadzenia dokładniejszego badania albo dochodzenia oraz w sposób oczywisty wskazują na nieważnośc'" '11. Decyzja biskupa o przekazaniu sprawy do procesu zwyczajnego ma mieć formalnie postać dekretu przedstanowczego, który nie kończy prowadzenia sprawy w ramach instancji, ale daje możliwość dalszego działania.

\section{Zakończenie}

Powyższe zestawienie dwóch procesów specjalnych, których prowadzenie przewiduje prawo kanoniczne, ukazuje głęboki wymiar pracy duszpasterskiej na rzecz małżeństwa jaka dokonuje się w sądownictwie kościelnym. Ustanowione przez Prawodawcę dwie drogi orzeczenia nieważności małżeństwa w formule skróconej bez

\footnotetext{
${ }^{49}$ Zob. Franciszek, Il vescovo è padre, capo e giudice dei fedeli. Przemówienie Ojca Świętego, 25.11. 2017, w: L’Osservatore Romano, 26.11.2017, s. 7.

${ }^{50}$ Por. P. Moneta, La dinamica processuale nel m.p. „,Mitis Iudex”, Ius Ecclesiae 28 (2016), s. 59.

${ }^{51}$ Por. kan. $1683,2^{\circ}$ KPK/MIDI.
} 
wątpienia przyspieszają proces decyzyjny. Są one jednak możliwe do zastosowania w szczególnych okolicznościach. Łączy je jednak klarowność nieważności, która uchyla konieczność prowadzenia procesu zwykłego. Z jednej strony podobne, różnią się jednak między sobą znaczeniem, zwłaszcza gdy popatrzymy na osobę sędziego i jego działalność. Obydwa procesy wpisują się w szeroko rozumianą duszpasterskość prawa kanonicznego, która staje się narzędziem na rzecz salus animarum. W obydwu procesach zostają jednak zachowane wszystkie podstawowe gwarancje sprawiedliwości procesowej: niezawisły i bezstronny sędzia, równość stron czy prawo do obrony. Wobec powyższego jedynie od stron i jakości materiału dowodowego faktycznie zależy wniesienie prośby o nieważność małżeństwa na drogę procesu dokumentalnego albo procesu skróconego przed biskupem.

\section{The documentary process and the briefer matrimonial process before the bishop -special processes in a case of nullity of the matrimonial}

The Code of Canon Law, which was reformed in 2015, gives the opportunity to bring proceedings for the nullity of marriage in two special forms. The first is the documentary process. The briefer process before the bishop was introduced to the Code in 2015 for the Pope Francis. Both trials are a unique form of a nullity of marriage. A thorough analysis of them shows many differences, but also similarities. Particular attention deserves the person of a judge. In both trials, however, all basic guarantees of procedural justice are preserved: an independent and impartial judge, equality of parties and the right to defense.

SŁOWA KLUCZOWE: nieważność małżeństwa; proces; dokument; biskup; forma specjalna

KEYWORDS: nullity of marriage; process; document; bishops; special forms

\section{Nota O AUTORZE}

Dr AdAm BARTCZaK - adiunkt w Katedrze Teorii i Filozofii Prawa na Wydziale Prawa i Administracji Uniwersytetu Łódzkiego, obrońca węzła małżeńskiego w Trybunale Metropolitalnym Łódzkim, adwokat kościelny. 